\author{
dr Katarzyna ŻAK \\ Wydział Zarządzania, Uniwersytet Ekonomiczny w Katowicach \\ e-mail: katarzyna.zak@ue.katowice.pl
}

DOI: $10.15290 /$ ose.2017.02.86.06

\title{
ANALIZA I OCENA EKSPANSJI ZAGRANICZNEJ POLSKICH PRZEDSIĘBIORSTW
}

\begin{abstract}
Streszczenie
Przemiany dokonujące się po 1989 roku oraz akcesja do Unii Europejskiej uruchomiły i zdynamizowały procesy umiędzynarodowienia zarówno polskiej gospodarki, jak i podmiotów działających w jej ramach. W pierwszej części artykuł przedstawia ogólne rozważania związane z internacjonalizacją działania, motywami, jakimi kierują się inwestorzy, oraz charakterystykę różnych form ekspansji na rynki zagraniczne. Zasadniczym celem drugiej części artykułu było przedstawienie diagnozy wybranych form aktywności polskich przedsiębiorstw na rynkach zagranicznych, takich jak: eksport, franchsing i bezpośrednie inwestycje zagraniczne. W artykule zastosowano metodę krytycznej analizy piśmiennictwa i wykorzystano różne zestawienia zawierające dane statystyczne takich instytucji, jak: Główny Urząd Statystyczny, NBP i UNCTAD.
\end{abstract}

Słowa kluczowe: ekspansja zagraniczna, eksport, franchising, bezpośrednie inwestycje zagraniczne (BIZ)

\section{ANALYSIS AND EVALUATION OF FOREIGN EXPANSION OF POLISH ENTERPRISES}

\section{Summary}

The transformation which took place after 1989 and the accession to the European Union provided a boost to the internationalization of the Polish economy and individual business companies. The first part of this paper presents general considerations associated with internationalization activities, the motives which guide investors, and the characteristics of different forms of expansion into foreign markets. The main purpose of the second part of the paper is to offer a diagnosis of selected forms of activity of Polish companies on foreign markets, such as export, franchising, and direct foreign investment. The paper uses the method of critical literary analysis and bases on a variety of statistical data from such institutions as: Central Statistical Office of Poland, NBP, and UNCTAD.

Key words: internalization, export, franchising, foreign direct investment (FDI)

JEL: F100, F210, F230, F630 


\section{Wstęp}

Rozpoczęta w 1989 roku transformacja polskiej gospodarki oraz przystapienie Polski do Unii Europejskiej (w $2004 \mathrm{roku}$ ) z pewnością były przełomowymi wydarzeniami i przyczyniły się do otwarcia polskiej gospodarki na świat oraz wkroczenia polskich przedsiębiorstw na nowe rynki.

Do niedawna podejmowanie aktywności na arenie międzynarodowej było domeną dużych podmiotów. Dziś ekspansja międzynarodowa jest ważnym elementem strategii także znaczenie mniejszych przedsiębiorstw.

Można wskazać wiele przesłanek, które mobilizują menedżerów do ekspansji na rynki zagraniczne, np.: zwiększenie skali działania, obniżka kosztów, dostęp do źródeł finansowania i zaopatrzenia, łatwiejszy dostęp do nowych rynków, silna konkurencja na dotychczasowych rynkach działalności przedsiębiorstwa, polityka krajów goszczących itp.

W przypadku wielu przedsiębiorstw operowanie w skali jedynie polskiego rynku już nie wystarczy. Do dalszego rozwoju jest niezbędna ekspansja na rynki zagraniczne, przy czym jest ona możliwa w różnych formach. Obecnie, oprócz eksportu, polscy przedsiębiorcy realizują swą aktywność w bardziej zaawansowanych formach, a szczególnego znaczenia nabierają bezpośrednie inwestycje zagraniczne.

Zakłada się więc, że w celu intensywniejszego rozwoju polskich przedsiębiorstw konieczne jest zróżnicowanie form obecności na rynkach zagranicznych oraz uzyskiwanie w zwiazku z tym coraz lepszych rezultatów ekonomicznych.

Celem artykułu jest prezentacja i charakterystyka wybranych form umiędzynarodowienia polskich przedsiębiorstw, a także wskazanie głównych kierunków ekspansji na rynki zagraniczne.

W artykule zastosowano metodę krytycznej analizy piśmiennictwa i wykorzystano różne materiały zawierające dane statystyczne takich instytucji, jak: Główny Urząd Statystyczny, NBP i UNCTAD.

\section{Internacjonalizacja przedsiębiorstw - konceptualizacja problemu}

Do końca lat pięćdziesiątych XX wieku w literaturze przedmiotu dominowały rozważania nad stosunkami między gospodarkami narodowymi - a więc podejście makroekonomiczne. Natomiast w drugiej połowie XX wieku pojawiło się wiele teorii internacjonalizacji (umiędzynarodowienia) przedsiębiorstw, co należy wiązać z takimi faktami, jak:

- rosnąca ekspansja przedsiębiorstw w formie eksportu;

- $\quad$ rosnące bezpośrednie zaangażowanie przedsiębiorstw na rynkach zagranicznych;

- $\quad$ rosnące zróżnicowanie form ekspansji przedsiębiorstw na rynki zagraniczne [Witek- Hajduk, 2010, s. 25].

Internacjonalizacja jest pojęciem interdyscyplinarnym, tzn. dotyczy zagadnień o charakterze: ekonomicznym, polityczno-prawnym, technologicznym i socjokulturowym. Można ją także definiować na różnych poziomach, a mianowicie:

- globalnym - gospodarki światowej; 
- $\quad$ makro - gdy odnosi się do umiędzynarodowienia gospodarki narodowej;

- mezo - gdy odnosi się do umiędzynarodowienia poszczególnych sektorów, branż gospodarki;

- $\quad$ mikro - gdy odnosi się do umiędzynarodowienia przedsiębiorstw;

- mikro-mikro - gdy odnosi się do umiędzynarodowienia wewnątrz przedsiębiorstwa [Przedsiebiorstwo na rynku miedrynarodonym. Analiza strategiczna, 1994, s. 15].

Literatura przedmiotu zawiera wiele różnych definicji internacjonalizacji przedsiębiorstwa, łącząc ją m.in. z: formami umiędzynarodowienia, geograficznym rozszerzaniem zakresu działania przedsiębiorstwa na rynki zagraniczne, zaangażowaniem zasobów przedsiębiorstwa za granica, umiędzynarodowieniem łańcucha wartości, wchodzeniem przedsiębiorstw w relacje w ramach sieci biznesowych [por. Rymarczyk, 2004, s. 19; Wspótczesne problemy marketingu miedzynarodowego, 1998, s. 27; Pietrusiński, 2005, s. 15; Gorynia, 2007, s. 35 i 88].

Zdaniem G. Albuma, J. Strandskova, E. Duerra i L. Dowda, umiędzynarodowienie przedsiębiorstwa oznacza sukcesywny rozwój jego międzynarodowego zaangażowania, mierzony rozszerzeniem geograficznego zasięgu rynków, produktów i form działalności, a także zmianami w ,filozofii zarządzania” przedsiębiorstwem i zachowaniach organizacji. Jest to tzw. eklektyczna definicja internacjonalizacji przedsiębiorstwa. Ponadto, internacjonalizację przedsiębiorstwa należy postrzegać w trzech wymiarach, tj.: jako proces (ujęcie dynamiczne, procesowe), jako rezultat (ujęcie statyczne) oraz jako sposób myślenia (ujęcie behawioralne) [Rymarczyk, 2004, s. 19; Album, Strandskov, Duerr, Dowda, 1994, s. 2].

Za najbardziej zaawansowany etap umiędzynarodowienia uznaje się globalizację. Zorska zdefiniowała ja jako długookresowe integrowanie: działań, procesów oraz podmiotów na poziomie: makro (gospodarki), mezo (branż i sektorów) oraz mikro (przedsiębiorstw) w ogólnoświatowy system przez rozszerzanie i intensyfikowanie powiązań zarówno handlowych, jak i inwestycyjnych, informacyjnych i innych [Zorska, 1998, s. 13 i dalsze]. Natomiast A. K. Koźmiński dodał, że zasadnicza różnica między umiędzynarodowieniem a globalizacja polega na zasiegu: w pierwszym przypadku zasięg ten obejmuje kilka krajów, w stosunku do globalizacji - cały globalny rynek [Koźmiński, 1999, s. 23; Nowakowski, 1999, s. 26].

Wielu autorów zwraca uwagę na rozróżnienie internacjonalizacji czynnej i biernej. Internacjonalizacja czynna (aktywna) jest to ekspansja zagraniczna przedsiębiorstwa w różnych możliwych formach. Internacjonalizacja bierna (pasywna) oznacza natomiast wchodzenie w różne związki gospodarcze z partnerami zagranicznymi bez wychodzenia z działalnościa gospodarcza poza granice kraju lokalizacji danej firmy. Inne z kolei podejście głosi, iż z internacjonalizacją bierna mamy do czynienia wówczas, gdy przedsiębiorstwo krajowe jest zmuszone do konkurowania na rynku macierzystym z firmami zagranicznymi, a z internacjonalizacją aktywna, gdy przedsiębiorstwo krajowe konkuruje na rynkach zagranicznych [Gorynia, 2007, s. 35; Rozkwitalska, 2007, s. 122; Gołębiowski, Witek- Hajduk, 2007, s. 16-17].

Obok zjawiska internacjonalizacji, w niektórych publikacjach można spotkać się z pojęciem deinternacjonalizacji. Mellaahi zdefiniował ja jako proces dobrowolnego zmniejszania zaangażowania przedsiębiorstwa w działania na rynku międzynarodowym. Jest 
ona zwykle odpowiedzią na pogorszenie sytuacji przedsiębiorstwa na rynku macierzystym lub za granicą bądź sposobem na poprawę rentowności przedsiębiorstwa w warunkach kryzysu [Mellahi, 2003, s. 151].

Wieloletnie badania, dotyczące problematyki internacjonalizacji przedsiębiorstw, doprowadziły do wykreowania wielu teorii w tej dziedzinie (tabela 1.).

TABELA 1.

\section{Wybrane teorie internacjonalizacji przedsiębiorstw}

\begin{tabular}{|c|c|c|c|}
\hline \multicolumn{2}{|c|}{ Grupa teorii } & Teoria & Przedstawiciele \\
\hline \multicolumn{2}{|c|}{$\begin{array}{l}\text { Teorie handlu międzynaro- } \\
\text { dowego }\end{array}$} & $\begin{array}{l}\text { Teorie neotechnologiczne, w tym teo- } \\
\text { ria luki technologicznej, teoria cy- } \\
\text { klu życia produktu }\end{array}$ & $\begin{array}{l}\text { M. Posner, R. Vernon, S. Hirsch, } \\
\text { R.R. Shons }\end{array}$ \\
\hline \multirow{6}{*}{ 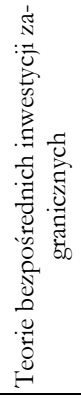 } & \multirow{2}{*}{$\begin{array}{l}\text { Nurt mono- } \\
\text { polu }\end{array}$} & $\begin{array}{l}\text { Teoria monopolistycznej przewagi } \\
\text { przedsiębiorstwa }\end{array}$ & S. Hymer \\
\hline & & $\begin{array}{l}\text { Teoria reakcji przedsiębiorstwa na } \\
\text { warunki konkurencji typu oligopo- } \\
\text { listycznego }\end{array}$ & F.T. Knickerbrocker \\
\hline & \multirow{3}{*}{$\begin{array}{l}\text { Nurt efektyw- } \\
\text { ności }\end{array}$} & Teoria internalizacji & P. Buckley, M. Cassone \\
\hline & & Teoria kosztów transakcyjnych & O.E. Williamson \\
\hline & & $\begin{array}{l}\text { Model analizy kosztów transakcyj- } \\
\text { nych }\end{array}$ & E. Anderson, H. Gatignon \\
\hline & $\begin{array}{l}\text { Teorie eklek- } \\
\text { tyczne }\end{array}$ & $\begin{array}{l}\text { Eklektyczna teoria produkcji mię- } \\
\text { dzynarodowej }\end{array}$ & J.H. Dunning \\
\hline \multirow{3}{*}{\multicolumn{2}{|c|}{$\begin{array}{l}\text { Teorie etapowej internacjo- } \\
\text { nalizacji przedsiębiorstwa }\end{array}$}} & Model uppsalski & $\begin{array}{l}\text { J. Johnson, F. Wiedersheim- } \\
\text {-Paul }\end{array}$ \\
\hline & & $\begin{array}{l}\text { Innowacyjne modele internacjonali- } \\
\text { zacji }\end{array}$ & $\begin{array}{l}\text { W.J. Bilkey, G. Tesar, } \\
\text { M.R. Czinkota, J.S. Lim, } \\
\text { K.I. Kim, R. Reid, T.R. Rao }\end{array}$ \\
\hline & & Modele fińskie & $\begin{array}{l}\text { R. Luostarinen, } \\
\text { J. Larimo, H. Hellman }\end{array}$ \\
\hline \multicolumn{2}{|c|}{ Teorie sieciowe } & Teorie sieciowej internacjonalizacji & $\begin{array}{l}\text { J. Johnson, L.G. Mattsson, } \\
\text { H. Hakanson }\end{array}$ \\
\hline \multicolumn{2}{|c|}{$\begin{array}{l}\text { Teorie wczesnej internacjo- } \\
\text { nalizacji }\end{array}$} & $\begin{array}{l}\text { Model powstania międzynarodo- } \\
\text { wych, nowych przedsiębiorstw }\end{array}$ & P.P. McDougall, B.M. Oviatt \\
\hline \multirow{3}{*}{\multicolumn{2}{|c|}{$\begin{array}{l}\text { Alternatywne teorie interna- } \\
\text { cjonalizacji }\end{array}$}} & Model podejścia strategicznego & S. Young \\
\hline & & $\begin{array}{l}\text { Model procesu podejmowania de- } \\
\text { cyzji }\end{array}$ & $\begin{array}{l}\text { F. Root, V. Kumar, V. Subramaniam, } \\
\text { Y. Pan, D. Tse, T. Eicher }\end{array}$ \\
\hline & & Model możliwości organizacyjnych & $\begin{array}{l}\text { P. Aulakti, M. Kotabe, } \\
\text { A. Madhok }\end{array}$ \\
\hline
\end{tabular}

Źródło: [Witek- Hajduk, 2010, s. 29].

\section{Motywy ekspansji na rynki zagraniczne}

Tak jak trudno przywołać jedno określenie internacjonalizacji, podobnie problematyczne jest wskazanie określonej grupy motywów, które są brane pod uwagę przez przedsiębiorstwo podejmujące aktywność na rynkach zagranicznych. W literaturze przedmiotu dominują dwa podejścia (tabela 2.). Pierwsze z nich wskazuje na takie czynniki, jak: 
rynkowe, kosztowe, zaopatrzeniowe oraz polityczne. Natomiast drugie podejście dzieli motywy internacjonalizacji przedsiębiorstwa na:

- $\quad$ proaktywne - które występują gdy przedsiębiorstwo dąży do zmiany strategii działania, ponieważ ma specjalne kompetencje i zasoby, bądź gdy dostrzega w otoczeniu szanse działania na rynkach zagranicznych;

- reaktywne - to takie, w odniesieniu do których firma reaguje na pewne siły na rynku macierzystym albo na rynkach zagranicznych i stara się do nich dostosować [Album, Strandskov, Duerr, Dowda, 1994, s. 40-46].

TABELA 2.

Motywy podejmowania międzynarodowej ekspansji przedsiębiorstw

\begin{tabular}{|c|c|}
\hline Grupa czynników & Wyszczególnienie \\
\hline Rynkowe & $\begin{array}{l}\text { Poszukiwanie nowych rynków zbytu. } \\
\text { Efektywniejsze wykorzystanie mocy wytwórczych. } \\
\text { Zwiększenie konkurencyjności na rynku macierzystym. } \\
\text { Dynamiczny rozwój rynków zagranicznych. } \\
\text { Zaostrzenie działań na dotychczasowych rynkach zagranicznych. }\end{array}$ \\
\hline Kosztowe & $\begin{array}{l}\text { Uzyskiwanie efektu skali produkcji. } \\
\text { Korzyści krzywej doświadczenia. } \\
\text { Możliwości obniżenia kosztów robocizny, eliminacja kosztów transportu surowców i ma- } \\
\text { teriałów. } \\
\text { Łatwiejszy dostęp do środków finansowych za granicą i niższy koszt ich pozyskania. } \\
\text { Ograniczenie ryzyka sprzedaży na jednym krajowym rynku i uniezależnienie się od wahań } \\
\text { koniunktury na tym rynku. }\end{array}$ \\
\hline Zaopatrzeniowe & $\begin{array}{l}\text { Możliwość pozyskania: surowców, materiałów i energii po cenach niższych niż na rynku } \\
\text { krajowym. } \\
\text { Możliwość pozyskania: surowców, materiałów i energii wówczas, gdy brakuje ich na rynku } \\
\text { krajowym - konieczność zapewnienia ciagłości zaopatrzenia w surowce. }\end{array}$ \\
\hline Polityczne & $\begin{array}{l}\text { Wynikają z polityki handlu zagranicznego państw zarówno macierzystych, jak i goszczących. } \\
\text { Wykorzystywane narzędzia to np.: system ubezpieczeń eksportu, ulgi w podatku dochodo- } \\
\text { wym, zwrot podatku VAT, ograniczenie stawek celnych. }\end{array}$ \\
\hline Proaktywne & $\begin{array}{l}\text { Oczekiwanie osiagnięcia zysku (w dłuższym okresie) z działania na rynkach zagranicznych. } \\
\text { Posiadanie przewagi technologicznej nad międzynarodową konkurencją. } \\
\text { Dysponowanie asortymentem produktów o unikatowych cechach (np.: wzornictwo, } \\
\text { walory smakowe, jakość wykonania, możliwość adaptacji do indywidualnych potrzeb } \\
\text { klientów) lub produkowanych po wyjątkowo niskich kosztach. } \\
\text { Posiadanie przewagi informacyjnej - duża wiedza o zagranicznych rynkach zbytu i/lub } \\
\text { klientach. } \\
\text { Oczekiwanie osiagnięcia korzyści skali i zdobycia oraz wykorzystania doświadczenia między- } \\
\text { narodowego. } \\
\text { Długookresowe planowanie działań marketingowych za granicą. } \\
\text { Osobiste zaangażowanie zarządu przedsiębiorstwa w proces umiędzynarodowienia. }\end{array}$ \\
\hline Reaktywne & $\begin{array}{l}\text { Presja konkurencyjna na rynku krajowym. } \\
\text { Obserwacja korzyści, jakie konkurenci osiagaja, umiędzynarodawiając swoją działalność. } \\
\text { Nadprodukcja w branży i samym przedsiębiorstwie, gromadzenie się zapasów. } \\
\text { Spadek sprzedaży produktów na rynku krajowym, np. w wyniku osiagnięcia schyłkowej } \\
\text { fazy cyklu życia rynkowego przez dany produkt lub nasycenia rynku macierzystego. } \\
\text { Nadmierne / nie w pełni wykorzystane moce produkcyjne. } \\
\text { Bliskość zagranicznych rynków zbytu (obszary przygraniczne, kraje sąsiednie) i/lub } \\
\text { portów międzynarodowych. } \\
\text { Zapytania ofertowe z zagranicy lub zamówienia z zagranicy. }\end{array}$ \\
\hline
\end{tabular}

Źródło: opracowanie na podstawie: Rymarczyk, 1996, s. 58-67; Album, Strandskov, Duerr, Dowda, 1994, s. 40-46]. 
Zintegrowane podejście do motywów podejmowania decyzji o międzynarodowej ekspansji przedsiębiorstw opiera się na uwzględnieniu warunków - szans i zagrożeń - otoczenia międzynarodowego i krajowego (makrootoczenia i otoczenia sektorowego) oraz potencjału samego przedsiębiorstwa, czyli jego atutów i słabości (rysunek 1.). Przedsiębiorstwa działające w kontekście różnorodnych warunków otoczenia dalszego i sektorowego, zarówno w kraju, jak i za granica, są narażone na oddziaływanie ryzyka systematycznego, co w praktyce oznacza, iż otoczenie takie generuje więcej zagrożeń niż szans. Natomiast ryzyko specyficzne wynika ze zidentyfikowanych atutów i słabości. Im silniejszy jest potencjał danego przedsiębiorstwa, tym niższe ryzyko specyficzne oraz tym lepsze są jego predyspozycje do podjęcia ekspansji na rynki zagraniczne.

Syntetyczna ocena sytuacji przedstawionych w tabeli 3. wskazuje, że okoliczności najkorzystniejsze do podjęcia decyzji o ekspansji międzynarodowej są wtedy, gdy w otoczeniu krajowym i międzynarodowym szanse przeważają nad zagrożeniami, a przedsiębiorstwo posiada silny potencjał wewnętrzny. W sytuacji, w której przedsiębiorstwo ma wiele atutów, a otoczenie zagraniczne oferuje więcej szans niż otoczenie krajowe, następuje efekt „wypychania” przedsiębiorstw na rynki międzynarodowe.

TABELA 3.

Macierz wpływu uwarunkowań otoczenia międzynarodowego i krajowego oraz potencjału przedsiębiorstwa na decyzje o podjęciu ekspansji międzynarodowej

\begin{tabular}{|c|c|c|c|c|c|c|c|}
\hline $\begin{array}{l}\text { Potencjał oto- } \\
\text { czenia między- } \\
\text { narodowego }\end{array}$ & $\begin{array}{l}\text { Więcej szans, } \\
\text { mniej zagrożeń }\end{array}$ & $\begin{array}{l}\text { Więcej szans, } \\
\text { więcej zagrożeń }\end{array}$ & $\begin{array}{l}\text { Więcej szans, } \\
\text { mniej zagro- } \\
\text { żeń }\end{array}$ & $\begin{array}{l}\text { Więcej szans, } \\
\text { więcej zagro- } \\
\text { żeń }\end{array}$ & $\begin{array}{l}\text { Więcej } \\
\text { szans, } \\
\text { mniej za- } \\
\text { grożeń }\end{array}$ & \begin{tabular}{|l} 
Więcej \\
szans, \\
więcej \\
zagro- \\
żeń
\end{tabular} & $\begin{array}{l}\text { Małe } \\
\text { szanse, } \\
\text { duże za- } \\
\text { grożenia }\end{array}$ \\
\hline $\begin{array}{l}\text { Potencjał oto- } \\
\text { czenia kra- } \\
\text { Poten- jowego } \\
\text { cjał przed- } \\
\text { siębiorstwa }\end{array}$ & \multicolumn{2}{|l|}{$\begin{array}{l}\text { Duże szanse, } \\
\text { małe zagrożenia }\end{array}$} & \multicolumn{2}{|c|}{$\begin{array}{l}\text { Duże szanse, } \\
\text { duże zagrożenia }\end{array}$} & \multicolumn{2}{|c|}{$\begin{array}{l}\text { Małe szanse, } \\
\text { małe zagrożenia }\end{array}$} & $\begin{array}{l}\text { Małe } \\
\text { szanse, } \\
\text { małe za- } \\
\text { grożenia }\end{array}$ \\
\hline $\begin{array}{l}\text { Dużo atutów, } \\
\text { mało słabości }\end{array}$ & $\begin{array}{l}\text { Warunki sprzy- } \\
\text { jające podjęciu } \\
\text { międzynarodo- } \\
\text { wej ekspansji }\end{array}$ & $\begin{array}{l}\text { Warunki sprzy- } \\
\text { jające podjęciu } \\
\text { międzynarodo- } \\
\text { wej ekspansji, } \\
\text { wyższe ryzyko } \\
\text { systematyczne }\end{array}$ & \begin{tabular}{|l|} 
Warunki sprzy- \\
jające podjęciu \\
międzynarodo- \\
wej ekspansji
\end{tabular} & $\begin{array}{l}\text { Warunki sprzy- } \\
\text { jające podjęciu } \\
\text { międzynarodo- } \\
\text { wej ekspansji, } \\
\text { wyższe ryzy- } \\
\text { ko systema- } \\
\text { tyczne }\end{array}$ & \multicolumn{2}{|c|}{$\begin{array}{l}\text { Warunki sprzyjaja- } \\
\text { ce podjęciu między- } \\
\text { narodowej ekspansji }\end{array}$} & \\
\hline $\begin{array}{l}\text { Dużo atutów, } \\
\text { dużo słabości }\end{array}$ & $\begin{array}{l}\text { Warunki sprzy- } \\
\text { jające podjęciu } \\
\text { międzynarodo- } \\
\text { wej ekspansji, } \\
\text { wyższe ryzyko } \\
\text { specyficzne }\end{array}$ & $\begin{array}{l}\text { Warunki sprzy- } \\
\text { jające podjęciu } \\
\text { międzynarodo- } \\
\text { wej ekspansji, } \\
\text { wyższe ryzyko } \\
\text { systematyczne } \\
\text { i specyficzne }\end{array}$ & $\begin{array}{l}\text { Warunki sprzy- } \\
\text { jające podjęciu } \\
\text { międzynaro- } \\
\text { dowej ekspa- } \\
\text { nsji, wyższe } \\
\text { ryzyko specy- } \\
\text { ficzne }\end{array}$ & \begin{tabular}{|l|} 
Warunki sprzy- \\
jające podjęciu \\
międzynaro- \\
dowej ekspa- \\
nsji, wyższe \\
ryzyko syste- \\
matyczne i spe- \\
cyficzne
\end{tabular} & & & \\
\hline $\begin{array}{l}\text { Mało atutów, } \\
\text { mało słabości }\end{array}$ & \multicolumn{2}{|c|}{$\begin{array}{l}\text { Warunki sprzyjające podjęciu } \\
\text { międzynarodowej ekspansji, wyż- } \\
\text { sze ryzyko systematyczne i spe- } \\
\text { cyficzne }\end{array}$} & & & & & \\
\hline $\begin{array}{l}\text { Mało atutów, } \\
\text { dużo słabości }\end{array}$ & & & & & & & \\
\hline
\end{tabular}

Źródło: [Gorczyńska, 2008, s. 50]. 
W warunkach silnego potencjału wewnętrznego, gdy na otoczenie międzynarodowe składa się więcej szans, ale i więcej zagrożeń, przedsiębiorstwa także podejmą międzynarodową ekspansję, lecz będzie ona obarczona wyższym ryzykiem systematycznym (ze względu na obecność zagrożeń). Natomiast w warunkach posiadania zarówno wielu atutów, jak i wielu słabości oraz występowania wielu szans na rynku krajowym i zagranicznym, również powstają sprzyjające warunki do ekspansji międzynarodowej, ale o podwyższonym ryzyku specyficznym

W sytuacji, gdy przedsiębiorstwo wyróżnia się licznymi atutami, lecz i licznymi słabościami, w każdej sytuacji, gdy zostanie podjęta decyzja o międzynarodowej ekspansji, będzie ona obarczona wyższym ryzykiem specyficznym, a w sytuacjach, gdy przedsiębiorstwa zdecydują się na ekspansję międzynarodową w warunkach otoczenia międzynarodowego, charakteryzującego się większą ilością szans i zagrożeń, dodatkowo większym ryzykiem systematycznym.

Międzynarodowa ekspansja o wysokim ryzyku systematycznym i specyficznym będzie występowała wówczas, gdy potencjał przedsiębiorstwa będzie cechował się małą ilością atutów i słabości. Ze względu na słabą pozycję zasobową niechętnie zostanie podjęta decyzja o wyjściu poza granice kraju, a jeśli już, to będzie obarczona wysokim ryzykiem specyficznym. Dla przedsiębiorstw o bardzo małej ilości atutów nawet niewielka ilość zagrożeń wiąże się z podwyższonym ryzykiem systematycznym.

\section{Od międzynarodowej ekspansji produktowej do międzynarodowej ekspansji kapitałowej}

W literaturze przedmiotu są prezentowane różne klasyfikacje sposobów wejścia przedsiębiorstwa na rynki zagraniczne. Podstawowymi kryteriami tych klasyfikacji są: zakres transferu kapitału za granicę, koszty wejścia, skala ryzyka, wycena szans i zagrożeń w otoczeniu międzynarodowym.

Wielu autorów traktuje wejście na rynki zagraniczne jako proces ${ }^{1}$, który jest realizowany w ramach kolejnych form, poczynając od handlu zagranicznego, poprzez formy bardziej złożone (umowy licencyjne, umowy franchisingowe), aż po utworzenie własnego przedsiębiorstwa za granicą [Meissner, 1981; Sznajder, 1995, s. 72].

Biorąc pod uwagę przedmiot ekspansji, można wyróżnić trzy zasadnicze formy ekspansji, tzn. produktową, zasobową i kapitałowa. Ekspansja produktowa obejmuje transakcje kupna i sprzedaży wyrobów i usług. Zasadniczą formą ekspansji produktowej jest eksport/import. Sa nimi także kontrakty, podczas których zachodzi sprzedaż bądź zakup specyficznych usług. Ekspansja zasobowa obejmuje działania, w ramach

${ }^{1}$ Współcześnie występują organizacje typu born global, które swoją egzystencją przeczą klasycznym teoriom internacjonalizacji (proces stopniowego, wieloetapowego angażowania się na rynkach zagranicznych). Definiuje się je jako firmy, które w ciagu trzech lat od swojego powstania rozpoczęły eksport o wielkości co najmniej 25 proc. sprzedaży i istnieją nie więcej niż 20 lat. Tradycyjne bariery umiędzynarodowienia działalności, takie jak brak wiedzy o rynkach zagranicznych czy też niewystarczające zasoby przedsiębiorstwa, wydają się tych firm nie ograniczać, a rozwój technologii komunikacyjnej, integracja międzynarodowa oraz zmniejszanie się barier między krajami częściowo tłumaczą przyspieszenie procesu internacjonalizacji przedsiębiorstw w tej formie. 
których następuje użycie bądź sprzedaż zasobów. Transfer zasobów może przebiegać jednokierunkowo lub partnerzy transferują zasoby między sobą, jednak bez łączenia kapitałów. Formami ekspansji zasobowej są licencjonowanie i franchising. Z kolei, ekspansja kapitałowa polega na zaangażowaniu kapitału na rynku zagranicznym w formie wspólnego przedsięwzięcia z partnerem zagranicznym (joint venture), w formie trwałego zaangażowania kapitałowego na rynku zagranicznym (fuzje i przejęcia na rynku zagranicznym - inwestycja brownfield) lub w formie stworzenia własnego przedsiębiorstwa na rynku zagranicznym (inwestycja greenfield).

Każda z wymienionych form międzynarodowej ekspansji może być rozpatrywana jako forma czynna lub bierna (rysunek 1.).

RYSUNEK 1.

Bierne i czynne formy ekspansji międzynarodowej przedsiębiorstwa

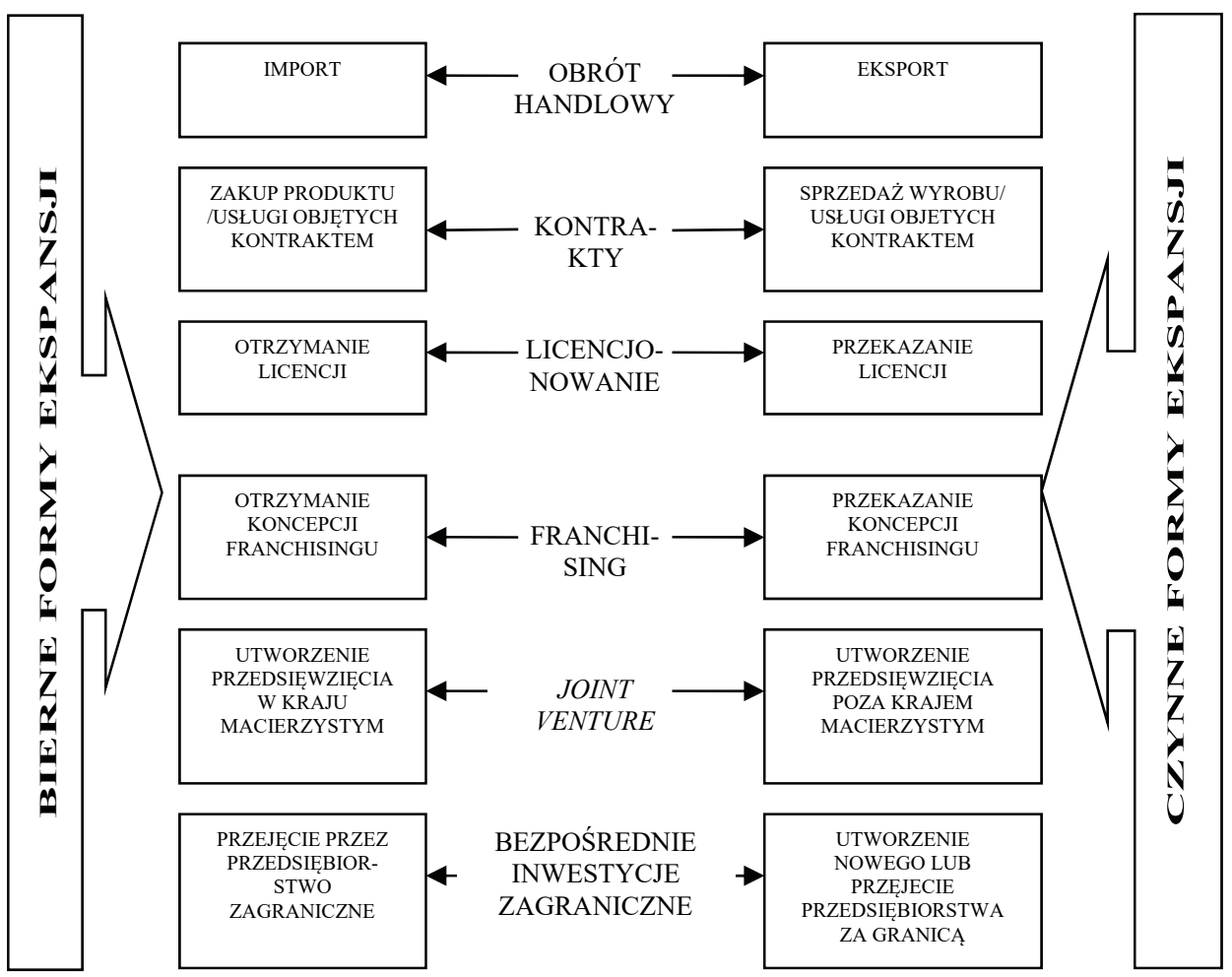

Źródło: opracowanie na podstawie: [Gorczyńska, 2008, s. 55].

Spośród przedstawionych na rysunku 1. czynnych i biernych form ekspansji nie wszystkie kwalifikują się do uznania za formy ekspansji międzynarodowej. Przedsiębiorstwa ekspansywne to takie, których działania są zorientowane na uzyskanie przewagi konkurencyjnej poza granicami kraju macierzystego. Takie przedsiębiorstwa, podejmując ekspansję międzynarodowa, wykorzystuja czynne formy, takie jak: eksport, sprzedaż 
wyrobów lub usług objętych kontraktem, udostępnienie licencji, udostępnienie koncepcji franchisingu, utworzenie joint venture z partnerem za granicą lub realizacja bezpośredniej inwestycji za granicą (BIZ). Zdarzają się przypadki, w których przedsiębiorstwo, dzięki biernemu uczestnictwu w danej formie oraz uczeniu się i zdobywaniu doświadczenia, przekształca się w uczestnika aktywnego [Karaszewski, 2004, s. 73-83].

\section{Przegląd wybranych form ekspansji polskich przedsiębiorstw na rynki zagraniczne}

Do niedawna inwestycje zagranicznych firm w Polsce przesłaniały ekspansję rodzimych przedsiębiorstw na rynki zagraniczne. Jednak obecnie ta sytuacja zmienia się. Wejście na rynek zagraniczny to naturalny kierunek rozwoju polskich przedsiębiorstw o ugruntowanej pozycji. Dla wielu polskich firm staje się jasne, że rodzimy rynek powoli staje się za mały. Wyjściem z takiej sytuacji może być ekspansja na rynki zagraniczne.

Umiędzynarodowienie przedsiębiorstw jest realizowane za sprawą wykorzystania różnych form ekspansji. Na podstawie danych opublikowanych przez Główny Urząd Statystyczny można stwierdzić, że polski eksport charakteryzuje się tendencją wzrostową i przyczynia się do rozwoju tej gospodarki (tabela 4.).

TABELA 4.

Wartość i dynamika zmian polskiego eksportu i importu w 2004 roku oraz w latach 2009-2015 (w mln euro, w \%)

\begin{tabular}{|l|r|r|r|r|r|r|r|r|}
\hline \multicolumn{1}{|c|}{$\begin{array}{c}\text { Wyszczególnie- } \\
\text { nie }\end{array}$} & $\mathbf{2 0 0 4}$ & $\mathbf{2 0 0 9}$ & $\mathbf{2 0 1 0}$ & $\mathbf{2 0 1 1}$ & $\mathbf{2 0 1 2}$ & $\mathbf{2 0 1 3}$ & $\mathbf{2 0 1 4}$ & $\mathbf{2 0 1 5}$ \\
\hline Eksport (w mln euro) & 59698 & 98218 & 120373 & 136694 & 143456 & 152779 & 165774 & 179578 \\
\hline $\begin{array}{l}\text { Dynamika zmian (w \%) } \\
\text { (rok do roku) }\end{array}$ & - & - & 123 & 114 & 105 & 106 & 108 & 108 \\
\hline Import (w mln euro) & 71354 & 107529 & 134188 & 152568 & 154040 & 155092 & 168432 & 177233 \\
\hline $\begin{array}{l}\text { Dynamika zmian (w \%) } \\
\text { (rok do roku) }\end{array}$ & - & - & 125 & 114 & 101 & 101 & 108 & 105 \\
\hline Saldo (w mln euro) & -11656 & -9311 & -13815 & -15874 & -10584 & -2313 & -2658 & 2345 \\
\hline
\end{tabular}

Źródło: opracowanie na podstawie: [Handel zagraniczny styczeńn - grudzień 2015; Handel zagraniczny styczeńn - grudzien 2013; Handel zagraniczny styczeń - grudzien 2011; Handel zagraniczny styczeńn - grudrieñ 2009].

Z danych zawartych w tabeli 4. wynika, że wartość polskiego eksportu w 2015 roku wyniosła blisko $180 \mathrm{mln}$ euro, a więc nastąił wzrost o $8 \% \mathrm{w}$ porównaniu z rokiem poprzednim. W okresie 2004-2015 systematycznie także wzrastał w Polsce import. W 2015 roku do Polski przywieziono z zagranicy towary o łącznej wartości 177,23 mld euro. W stosunku do 2014 roku był to wzrost o 5\%. Najwyższą dynamikę zmian można było zaobserwować w roku 2010 w stosunku do roku 2009, kiedy zarówno wartość eksportu, jak i importu wzrosły ponad $20 \%$. 
Porównując wartość eksportu w 2015 roku z rokiem 2004, można zauważyć, że wartość ta wzrosła trzykrotnie, a wartość importu - ponad dwukrotnie. Wyniki te świadczą o tym, iż rozwój gospodarczy Polski, w tym również wzrost eksportu - podobnie jak w większości gospodarek przechodzących proces transformacji w Europie Środkowej i Wschodniej - jest silnie uzależniony od napływu inwestycji zagranicznych, które z reguły są nośnikiem innowacji i technologii, ale jednocześnie generuja import o charakterze inwestycyjno-zaopatrzeniowym. Import ten bezpośrednio wpływa na rozwój potencjału produkcyjnego oraz unowocześnienie gospodarki, a jednocześnie wywiera decydujący wpływ na skalę deficytu obrotów. Można zatem oceniać, że wzrost importu - szczególnie szybki na początku transformacji - jest nieodłącznym i naturalnym elementem rozwoju polskiej gospodarki. Warto zarazem podkreślić, że napływ zagranicznych inwestycji, pociagający za sobą wzrost importu, po pewnym czasie generuje również przyspieszenie eksportowe w wyniku zaangażowania się tych podmiotów w działalność eksportową.

Na uwagę zasługuje fakt, iż deficyt handlowy od 2011 roku systematycznie malał (za wyjątkiem roku 2014). Natomiast w 2015 roku wartość polskiego eksportu przekroczyła wartość importu, co oznaczało, iż od wielu lat po raz pierwszy uzyskano dodatnie saldo wymiany handlowej z zagranicą (rysunek 2.).

RYSUNEK 2.

Wartość polskiego eksportu, importu i saldo handlu zagranicznego w 2004 roku oraz w latach 2009-2015 (w mln euro)

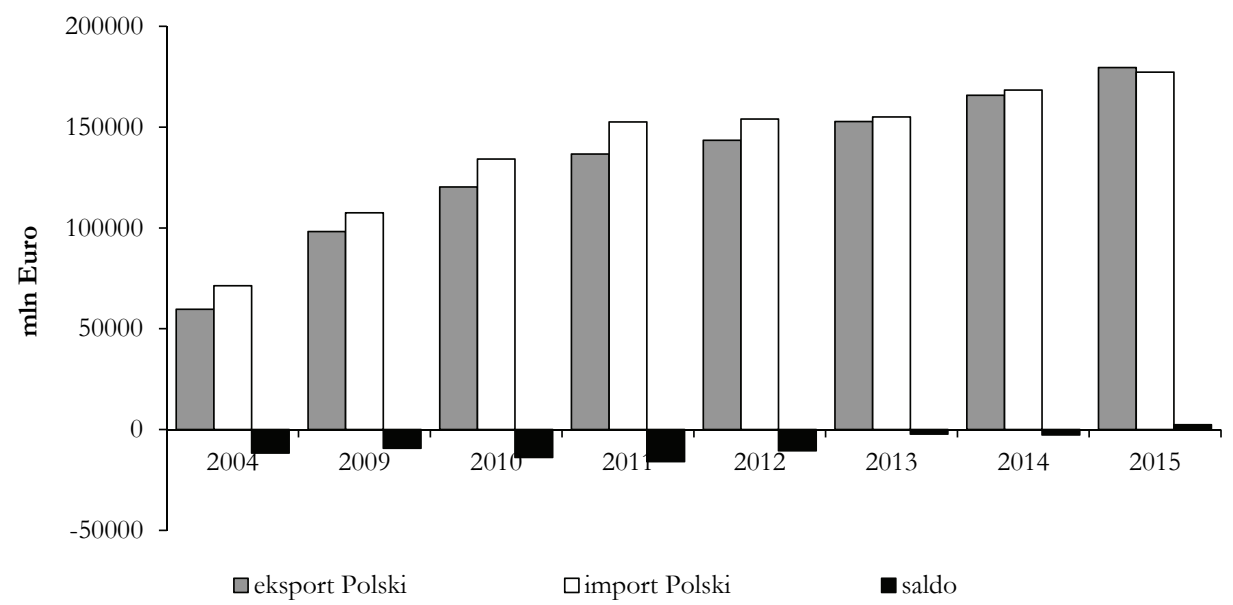

Źródło: opracowanie na podstawie: [Handel zagraniczny styczeń - grudzień 2015; Handel zagraniczny styczeń - grudzień 2013; Handel zagraniczny styczeñ - grudzień 2011; Handel zagraniczny styczeń - grudqień 2009].

W latach 2001-2015 można zaobserwować przeobrażenia struktury polskich obrotów towarowych z zagranicą w przekroju geograficznym (tabela 5.). Biorąc pod uwage aktywną formę ekspansji produktowej polskich przedsiębiorstw, należy zauważyć, iż 
głównym kierunkiem polskiego eksportu są kraje Unii Europejskiej, jednak w badanym okresie udział eksportu do tych krajów w 2015 roku zmniejszył się o 1,9\% w stosunku do roku 2001. W 2015 roku najważniejszym partnerem handlowym były Niemcy, które ogółem odpowiadały za zakup 27,1\% polskich produktów eksportowych. Wśród polskich partnerów handlowych kolejne pozycje po Niemczech zajmowały w eksporcie - Wielka Brytania (6,7\%), Czechy (6,6\%), Francja (5,5\%), Włochy (4,8\%) i Holandia $(4,4 \%)$.

TABELA 5.

Główne kierunki polskiego eksportu i importu w 2001 i 2015 roku (w \%)

\begin{tabular}{|l|c|c|c|c|c|c|}
\hline \multirow{2}{*}{ Wyszczególnienie } & \multicolumn{3}{|c|}{$\begin{array}{c}\text { Struktura eksportu } \\
\text { (w \%) }\end{array}$} & \multicolumn{3}{c|}{$\begin{array}{c}\text { Struktura importu } \\
\text { (w \%) }\end{array}$} \\
\cline { 2 - 7 } & $\mathbf{2 0 0 1}$ & $\mathbf{2 0 1 5}$ & Zmiana & $\mathbf{2 0 0 1}$ & $\mathbf{2 0 1 5}$ & Zmiana \\
\hline Unia Europejska & 81,3 & 79,4 & $-1,9$ & 69,8 & 60,0 & $-9,8$ \\
Pozaunijne kraje rozwinięte /USA, Japonia/ & 5,7 & 6,3 & $+0,6$ & 8,5 & 6,0 & $-2,5$ \\
Kraje WNP / Rosja, Ukraina, Białoruś/ & 7,0 & 5,3 & $-1,7$ & 10,5 & 8,6 & $-1,9$ \\
Pozostałe / Chiny, Indie/ & 6,0 & 9,0 & $+3,0$ & 11,2 & 25,4 & $+14,2$ \\
\hline
\end{tabular}

Źródło: opracowanie na podstawie: [Handel zagraniczny styczeń - grudžień 2015; Handel zagraniczny styczeñ - grudzien 2001].

Drugim, ważnym kierunkiem eksportu polskich produktów są kraje rozwijające się - ich udział wzrósł w badanym okresie o 3,0\%. Szczególne miejsce wśród tych krajów zajmują Chiny, Indie oraz Turcja, która obecnie jest traktowana jako jeden z perspektywicznych rynków dla polskiego eksportu. Trzeci pod względem udziału kierunek polskiego eksportu to pozaunijne kraje rozwinięte gospodarczo. Choć w omawianej strukturze wzrost ich udziału w 2015 roku w stosunku do 2001 roku jest niewielki, to można przypuszczać, iż na wymagających rynkach, takich jak USA czy Japonia, coraz śmielej moga konkurować polskie produkty. Czwartym kierunkiem ekspansji produktowej są kraje WNP, w tym m.in.: Rosja, Ukraina i Białoruś - w badanym okresie wartość eksportu zmniejszyła się o $1,7 \%$.

Zmiany, dotyczące polskiego eksportu w latach 2001-2015, obejmują również strukturę przedmiotową (rysunek 3.). Głównie polegają one na wzroście udziału wyrobów wyżej przetworzonych i o wyższym stopniu zaawansowania technologicznego, w tym przede wszystkim wyrobów elektromaszynowych, które w 2001 roku stanowiły 37\% eksportu ogółem, a 39\% w 2015 roku. W tym okresie znacząco wzrósł udział wyrobów chemicznych w polskim eksporcie - do 13,5\%. Hitem eksportowym firm $z$ nad Wisły są m.in.: nawozy, olejki eteryczne, preparaty perfumeryjne, mydła i preparaty piorące, a także artykuły z kauczuku.

W analizowanym okresie bardzo korzystnie wyróżniał się eksport artykułów rolno-spożywczych, który zwiększył się blisko o 60\%. O ile w roku 2001 stanowiły one 8,4\% eksportu ogółem z Polski, to w 2012 roku już 13,3\%. Szczególnie w minionych kilku latach produkty żywnościowe systematycznie umacniały swoją pozycję w polskim eksporcie i stały się jedną z naszych specjalności eksportowych. Polscy przedsiębiorcy przede wszystkim eksportują mięso: drobiowe, wołowe i wieprzowe, a także produkty mleczarskie, czekolady oraz rozmaite rodzaje pieczywa. Trzeba także zwrócić uwagę 
na imponującą sprzedaż soków owocowych i warzywnych oraz zamrożonych owoców (maliny, truskawki i wiśnie).

RYSUNEK 3.

\section{Struktura przedmiotowa polskiego eksportu w 2001 i 2015 roku (w \%)}

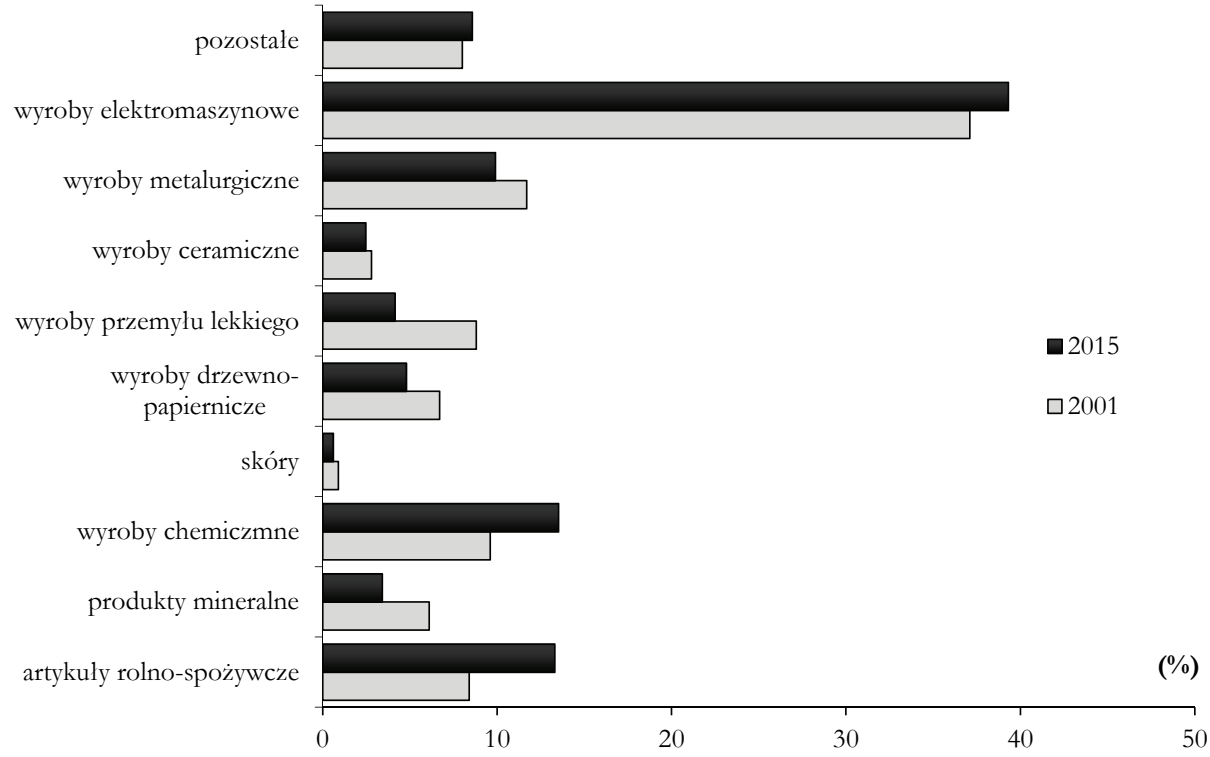

Źródło: opracowanie na podstawie: [Handel zagraniczny styczeń - grudzień 2015; Handel zagraniczny styczeń-grudzień 2001].

Z kolei, największe spadki udziału odnotowano w przypadku wyrobów przemysłu lekkiego (o blisko 50\%, do 4,14\%) oraz wyrobów przemysłu drzewno-papierniczego (o 30\%, do 4,79\%).

Od poczatku transformacji gospodarczej istotne miejsce w polskim handlu zagranicznym zajmują obroty usługami, a ich generalnie dodatni bilans w tym okresie łagodzi skalę deficytu w obrotach towarowych (rysunek 4.). Ważnym, pozytywnym wyróżnikiem eksportu usług jest także jego relatywnie wysokie przełożenie na aktywizację małych przedsiębiorstw, a w rezultacie na wzrost zatrudnienia. 
RYSUNEK 4.

Wartość eksportu i importu usług polskich przedsiębiorców w: 2001, 2004, 2008, 2012 i 2015 roku (w mln euro)

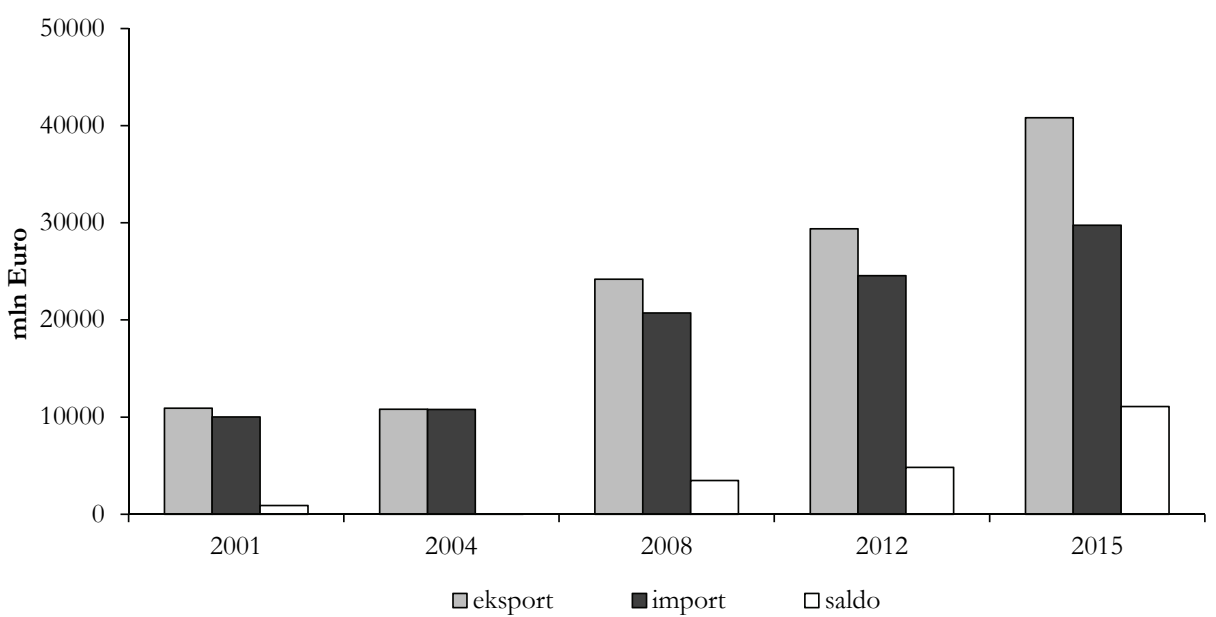

Źródło: opracowanie na podstawie: [Handel zagraniczny styczeń-grudzień 2015; Handel zagraniczny styczeń - grudzień 2013; Handel zagraniczny styczeń - grudzień 2008; Handel zagraniczny styczeń - grudzień 2004].

W latach 2001-2015 wpływy z eksportu usług wzrosły z 10,9 mld euro w roku 2001 do 40,8 mld euro w roku 2015, tj. 3,7-krotnie. W tym czasie wpływy z eksportu towarów wzrosły około 4,4-krotnie (z 39 mld euro do 172,6 mld euro), czyli znacznie szybciej.

W wymianie usług dominowały rynki Unii Europejskiej, szczególnie Niemcy i Czechy, natomiast wśród rynków pozaunijnych: Szwajcaria i USA, Ukraina i Rosja.

W ogólnej wartości przychodów z eksportu usług w ostatnich latach ponad połowa przypadła na dwie grupy, tj.: usługi transportowe (stanowiace 29,5\% w roku 2012) oraz usługi na rzecz podróżnych z zagranicy, w tym turystów (stanowiące 29,1\% ogólnych przychodów). Istotne znaczenie miały także patenty i licencje oraz usługi ubezpieczeniowe i finansowe.

Przykładem niekapitałowej ekspansji na rynki zagraniczne są umowy franchisingowe polskich przedsiębiorstw z partnerami zagranicznymi. Rodzime pomysły na prowadzenie biznesu w ramach umów franchisingowych na razie dość nieśmiało wkraczają na zagraniczne rynki. Z blisko 600 polskich sieci rozwijających się w kraju poprzez franczyzę tylko 45 zdecydowało się, jak dotąd, uruchomić placówki pod swoją marką, poza Polską. Tymczasem większość z nich ma niewiele takich jednostek. O szerzej zakrojonej ekspansji można mówić jedynie w kilku przypadkach.

Najczęściej polscy przedsiębiorcy zawierają umowy franchisingowe z partnerami zagranicznymi w takich branżach, jak: odziė̇, obuwie, galanteria skórzana, urządzanie 
wnętrz, gastronomia, FMCG (fast-moving consumer goods - produkty szybko rotujące, sprzedawane często i po względnie niskich cenach, np.: artykuły spożywcze, środki czystości.), salony urody, biura nieruchomości oraz usługi (tabela 6.).

Polskie sieci franczyzowe, rozwijane poza granicami naszego kraju, są obecne w sumie w ponad 40 państwach. Głównymi krajami ekspansji są kraje ościenne, jednak szczególnie południowi sąsiedzi i Litwa. W Czechach istnieje 19 polskich sieci, natomiast na Słowacji i na Litwie - po 17. Po kilkanaście marek pojawiło się już także w Rosji, na Ukrainie oraz w Rumunii. Natomiast Zachód pozostaje ogromnym wyzwaniem. Pojawienie się na Zachodzie jest już zdecydowanie trudniejsze.

W Niemczech swoją obecność zaznaczyło już 10 sieci. Na terenie pozostałych krajów dawnej Unii Europejskiej pojawiło się łącznie 11 sieci, lecz często są to pojedyncze placówki, np.: Miss Trendy oraz New York Hot Dog w Irlandii, Nasz Naleśnik w Anglii czy Organique i Perfect Moments w Szwecji. Jednocześnie można wskazać kilkadziesiąt krajów, nierzadko bardzo egzotycznych, w których pojawiły się placówki tylko jednej polskiej sieci, np.: w Armenii jest obecny Atlantic, w Libanie - Big Star, a w Chinach - Tatuum. Do Stanów Zjednoczonych udało się wejść dwom polskim sieciom franczyzowym - sklepom z kosmetykami Inglot oraz Ambasadom Urody Vacu Fit [Rozwój polskich sieci francżyowych zagranica 2010 (data wejścia: 15.05.2014)].

TABELA 6.

Przykłady polskich sieci franchisingowych działających na rynkach zagranicznych

\begin{tabular}{|c|c|c|c|}
\hline Marka & Branża & Rynki goszczące & $\begin{array}{l}\text { Liczba } \\
\text { placó- } \\
\text { wek }\end{array}$ \\
\hline $\begin{array}{l}\text { Reserved } \\
\text { Cropp }\end{array}$ & Odzież & $\begin{array}{l}\text { Litwa, Lotwa, Estonia, Rosja, Ukraina, Bułgaria, Rumu- } \\
\text { nia, Czechy, Słowacja }\end{array}$ & $\begin{array}{c}102 \\
66\end{array}$ \\
\hline Vacu Fit & Uroda & $\begin{array}{l}\text { Słowacja, Czechy, Węgry, Litwa, Niemcy, Holandia, } \\
\text { Belgia, Irlandia, Anglia, Portugalia, San Marino, Wło- } \\
\text { chy, Rosja, USA }\end{array}$ & 200 \\
\hline Żabka & Spożywcze & Czechy & $\begin{array}{c}\text { ponad } \\
100\end{array}$ \\
\hline Inglot & Uroda & $\begin{array}{l}\text { Australia, Zjednoczone Emiraty Arabskie, Kanada, } \\
\text { Wielka Brytania, Finlandia, Irlandia, Indie, Kuwejt, Li- } \\
\text { twa, Malta, Oman, Katar, Arabia Saudyjska, Serbia, } \\
\text { USA, Turcja, Ukraina }\end{array}$ & 70 \\
\hline Atlantic & Odzież & $\begin{array}{l}\text { Rosja, Ukraina, Litwa, Białoruś, Czechy, Słowacja, } \\
\text { Mołdawia, Armenia, Gruzja }\end{array}$ & 58 \\
\hline $\mathrm{CCC}$ & Buty & Czechy & 41 \\
\hline Meble Vox & $\begin{array}{l}\text { Urządzanie } \\
\text { wnętrz }\end{array}$ & $\begin{array}{l}\text { Białoruś, Bułgaria, Czechy, Estonia, Litwa, Lotwa, } \\
\text { Mołdawia, Niemcy, Rosja, Rumunia, Słowacja, Ukraina, } \\
\text { Węgry }\end{array}$ & 40 \\
\hline
\end{tabular}

Źródło: opracowanie na podstawie: [Rozwój polskich sieci franczyzonych za granicq..., 2010].

Polskie firmy coraz częściej inwestują za granica oraz zwiększają aktywność inwestycyjną na światowych rynkach. Warto przypomnieć, że na początku lat dziewięćdziesiątych XX wieku BIZ polskich firm stanowiły 0,01\% światowych przepływów $\mathrm{BIZ}$, natomiast już pod koniec pierwszej dekady XXI wieku wartość ta wzrosła do 
0,4\% (40 razy!). Bez wątpienia, obecnie zjawisko to stanowi istotny symptom przemian dokonujących się w polskiej gospodarce i określa poziom jej umiędzynarodowienia. Aktywność inwestycyjna świadczy o potencjale polskich przedsiębiorstw, które stają się aktywnymi uczestnikami systemu międzynarodowego obrotu kapitałami inwestycyjnymi.

Dynamiczny wzrost wartości bezpośrednich inwestycji lokowanych za granica przez polskie przedsiębiorstwa jest obserwowany od 2005 roku. W czerwcu 2011 roku po raz pierwszy w historii wartość skumulowana (okres: lipiec 2010-czerwiec 2011) polskich inwestycji bezpośrednich za granicą była równa skumulowanej rocznej wartości zagranicznych inwestycji bezpośrednich w Polsce w tym okresie.

Polska jest nie tylko największym w regionie odbiorca zagranicznych inwestycji, ale także największym źródłem, z którego kapitał wypływa (poza 2012 rokiem). Lata: 2010 i 2011 były rekordowe pod względem polskich inwestycji za granica, a ich wartość przekraczała 7 mld USD (rysunek 5.). W 2012 roku strumień odpływu BIZ był związany z wycofywaniem kapitału zainwestowanego za granica przez polskie przedsiębiorstwa.

RYSUNEK 5.

Wartość BIZ realizowanych przez: Polskę, Czechy, Słowację i Węgry (2005-2012)

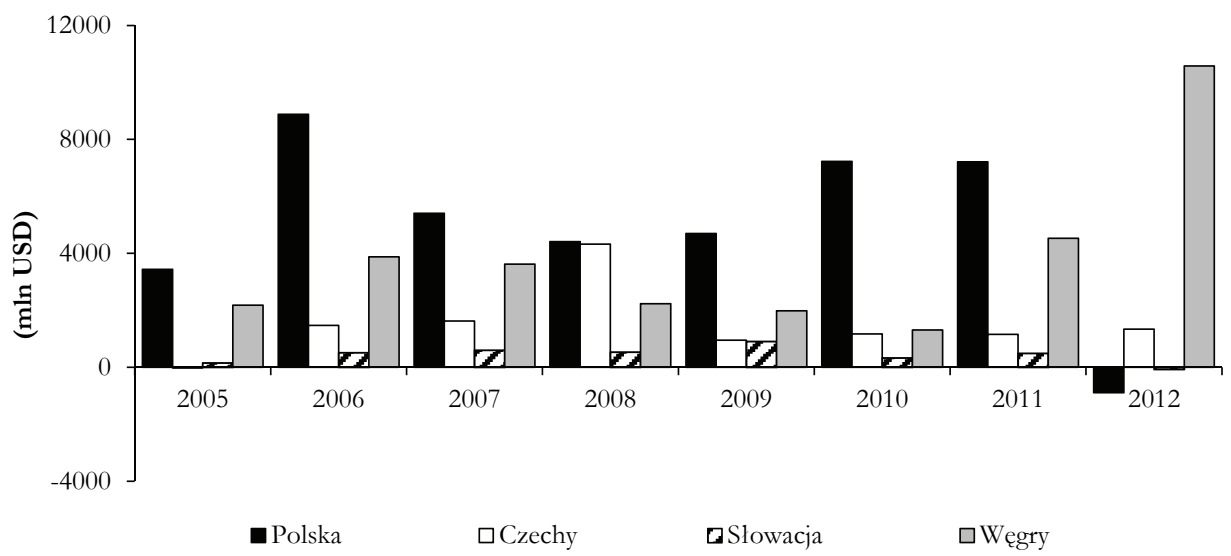

Źródło: opracowanie na podstawie: [World Investment Report, 2006; World Investment Report, 2009; World Investment Report, 2013].

Polscy przedsiębiorcy inwestowali w 94 krajach, w tym wszystkich z Unii Europejskiej, gdzie kapitał ulokowało 1980 spółek (w 2010 roku było ich 1 802). Ponad $50 \%$ działalności miało miejsce w krajach ościennych. Mierząc działalność liczbą spółek za granica, aż 52\% inwestycji trafiło do: Niemiec (427 podmiotów), na Ukrainę (355), do Czech (270) i Rosji (242).

Powodem przepływów kapitałowych do takich krajów, jak: Luksemburg, Holandia czy Cypr są korzystne przepisy podatkowe. Firmy rejestrują w tych krajach spółki i za 
ich pośrednictwem inwestuja. Te przepływy to tzw. kapitał w tranzycie. Polskie spółki dzięki takim zagranicznym spółkom mogą inwestować w Polsce, więc kapitał wraca. Z kolei, Belgia i Wielka Brytania to wielkie centra finansowe - tu są lokowane nadwyżki finansowe $z$ całej grupy kapitałowej.

Warto na tle wartości BIZ realizowanych przez polskich przedsiębiorców pokazać, jaki udział reprezentuja poszczególne formy tych inwestycji, tzn. greenfield i brownfield (rysunek 6.).

Na podstawie danych zawartych w World Investment Report 2016 można stwierdzić, iż w strukturze BIZ, realizowanych przez polskich przedsiębiorców w latach 2006-2011, dominowały inwestycje typu brownfield (strategie „nabyćc realizowane na rynkach zagranicznych). Ponad pięćdziesięcioprocentowy udział inwestycji typu greenfield zanotowano tylko w 2007 i 2008 roku. W 2012 roku projektów typu greenfield było niewiele. Spośród zrealizowanych projektów typu brownfield tylko jeden zasługuje na wyróżnienie zakup dokonany przez KGHM (KGHM zakupił za 2,8 mld dol. kanadyjską spółkę Quadra w 2012 roku).

RYSUNEK 6.

BIZ typu greenfield i brownfield polskich przedsiębiorców (2006-2015)

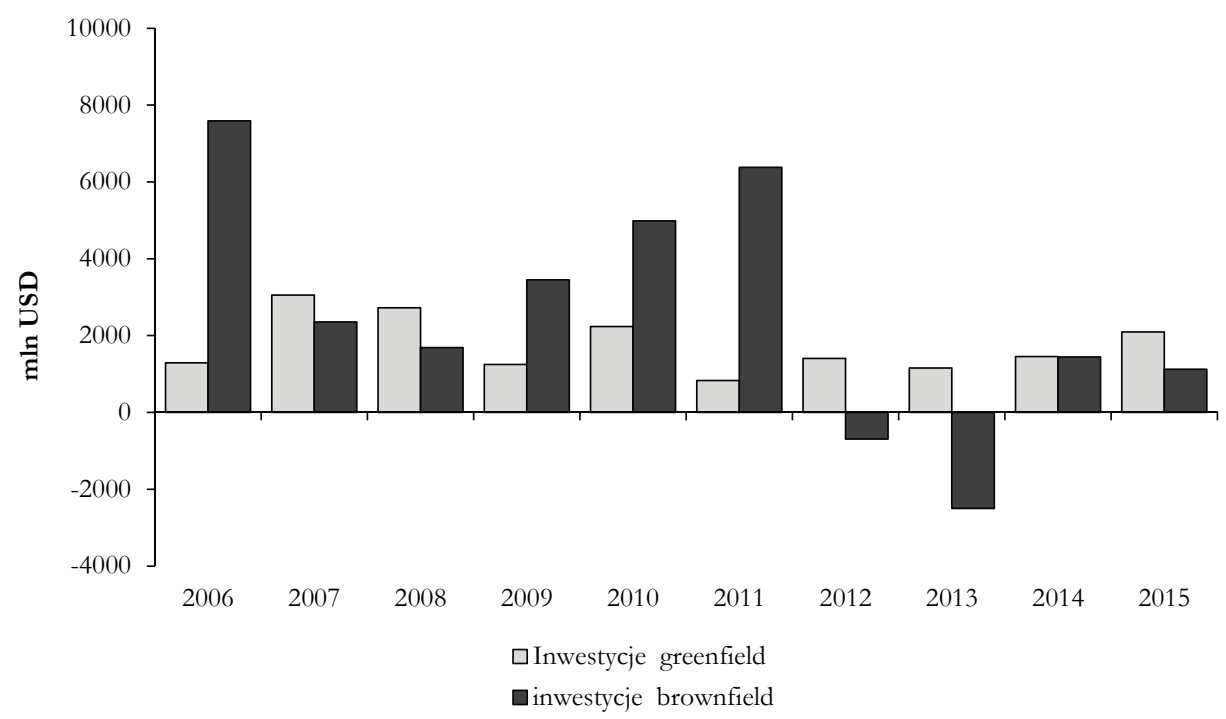

Źródło: opracowanie na podstawie: [World Investment Report, 2006; World Investment Report, 2009; World Investment Report, 2013].

Dane NBP świadczą o tym, że nie udało się powtórzyć sukcesu wartości BIZ z lat 2010-2011. W 2012 roku zanotowano polskie inwestycje zagraniczne na minusie. Ujemna wartość inwestycji brownfield w 2012 roku wynika z tego, iż część inwestorów z Polski wycofało udziały kapitałowe z rynków zagranicznych. Przede wszystkim nastapiło wycofanie inwestycji z sektora działalności finansowej i ubezpieczeniowej (-1 $270 \mathrm{mln}$ euro) 
oraz działalności: profesjonalnej, naukowej i technicznej (-1 $884 \mathrm{mln}$ euro). Podobna sytuacja wystapiła w 2013 roku, gdy odpływ inwestycji bezpośrednich polskich przedsiębiorstw z rynków zagranicznych sięgnął poziomu -2 501 mln USD. Od 2014 roku można ponownie zaobserwować wzrost zaangażowania polskich przedsiębiorców w bezpośrednie inwestycje zagraniczne, przy czym w 2015 roku dominowały inwestycje typu greenfield, co stanowiło 65\% ogółu BIZ realizowanych przez polskie przedsiębiorstwa. Głównymi kierunkami inwestowania były: Cypr i Szwajcaria, natomiast wycofywano inwestycje przede wszystkim z Luksemburga i Szwecji. W 2015 roku polskie inwestycje bezpośrednie za granica przede wszystkim trafiły do podmiotów bezpośredniego inwestowania zajmujących się działalnością finansową i ubezpieczeniową oraz górnictwem i wydobywaniem. Natomiast kapitał wycofywano z podmiotów związanych z działalnością: profesjonalna, naukowa i techniczną [Polskie imwestycje bespośrednie za granica w 2015 roku; Polskie inwestycje bespośrednie za granica w 2013 roku; Polskie inwestygje bespośrednie za granica w 2012 roku].

\section{Podsumowanie}

Tematyka międzynarodowej ekspansji zagranicznej jest aktualna i ważna zarówno z punktu widzenia przedsiębiorstwa (ujęcie mikro), jak i gospodarki narodowej oraz światowej. Przedstawiona analiza i ocena aktywności polskich przedsiębiorstw na rynkach zagranicznych pozwala wnioskować, iż w Polsce następuje stały rozwój ekspansji międzynarodowej w jej różnych formach, od eksportu, poprzez formy zasobowe i kapitałowe. Mimo intensyfikowania działalności gospodarczej polskich podmiotów gospodarczych, wartość eksportu (1\% wartości światowego eksportu), współpracy w ramach sieci franchisingowych czy bezpośrednich inwestycji zagranicznych $(0,4 \%$ światowych przepływów BIZ), w porównaniu z gospodarkami wysoko rozwiniętymi, jest niewielka. Można to, co prawda, tłumaczyć skutkami kryzysu w 2008 roku, który przyczynił się do spowolnienia aktywności inwestycyjnej na świecie i w Polsce. Pewnym pozytywnym sygnałem jest fakt, iż Polska zajmuje pozycję lidera wśród krajów Europy Środkowo-Wschodniej, co pozwala docenić jej potencjał i z optymizmem patrzeć w przyszłość

Zagraniczna ekspansja polskich przedsiębiorstw to także efekt rządowego wsparcia. W ostatnich latach administracja podjęła szereg skoordynowanych działań, które pomogły polskim firmom w ekspansji na rynki zagraniczne, a mianowicie:

- zaproszenie do udziału w misjach gospodarczych organizowanych przez samo tylko Ministerstwo Spraw Zagranicznych przedsiębiorstw (wzrost dziesięciokrotny w ciagu ostatnich dwóch lat - z 70 do 700 firm);

- program Ministerstwa Gospodarki „Go China” (od 2004 roku wartość polskiego eksportu do Chin wzrosła o 182 proc., do 5,7 mld zł w 2012 roku);

- rozpoczęty w 2013 roku program „Go Africa” (eksport w tym przypadku wzrósł od stycznia do lipca o 28 proc. r./r.) [Polskie inwestycje beappośrednie za granica w 2012 roku (data wejścia: 17.05.2014)] . 
Jednocześnie Polska Agencja Inwestycji i Handlu SA, zgodnie z umową zawartą z Ministrem Rozwoju, realizuje projekt pod nazwa: , Wspieranie polskich przedsiębiorstw na wybranych rynkach". Wydział Wspierania Polskich Inwestycji jest odpowiedzialny za udzielanie wsparcia polskim firmom zainteresowanym inwestowaniem za granica $\mathrm{w}$ formie bezpośrednich inwestycji lub fuzji i przejęć. Firmom zainteresowanym inwestowaniem za granica udziela się merytorycznej pomocy, polegającej m.in. na doradztwie w zakresie wyboru lokalizacji projektu czy wsparciu przy uzyskaniu pomocy rządowej dostępnej w wybranym kraju. Profesjonalne wsparcie obejmuje również dostarczenie przedsiębiorstwom odpowiednich zasobów informacyjnych niezbędnych do podjęcia decyzji inwestycyjnej, które umożliwią lepszą koncentrację na kluczowych rynkach czy organizowanie misji gospodarczych większych niż do tej pory.

\section{Literatura}

Album G., Strandskov J., Duerr E., Dowda L., 1994, International marketing and export management, Addison- Wesley, New York.

Gołębiowski T., Witek- Hajduk M. K., 2007, Formy internacjonalizacji polskich przeedsiebiorstw, „Marketing i Rynek”, nr 2.

Gorczyńska M., 2008, Miedsynarodowa ekspansja przedsiebiorstw, Wydawnictwo CeDeWu, Warszawa.

Gorynia M., 2007, Strategie zagranicznej elespansji przedsiebiorstw, Polskie Wydawnictwo Ekonomiczne, Warszawa.

Handel zagraniczny styczeńn - grudzień 2004, www.stat.gov.pl (data wejścia: 04.05.2017).

Handel zagraniczny styczeńn - grudzień 2008, www.stat.gov.pl (data wejścia: 04.05.2017).

Handel zagraniczny styczeńn - grudzień 2013, www.stat.gov.pl (data wejścia: 04.05.2017).

Handel zagraniczny styczeń - grudzień 2015, www.stat.gov.pl (data wejścia: 04.05.2017).

Karaszewski W., 2004, Bespośrednie inwestyyje zagraničnne. Polska na tle swiata, TNOiK Dom Organizatora, Torun.

Koźmiński A., 1999, Zarzadzanie miedsynarodowe, Polskie Wydawnictwo Ekonomiczne, Warszawa.

Meissner H. G., 1981, Aussenhandelsmarketing, Verlag Schaffer-Poeschel, Stuttgart.

Mellahi K., 2003, The de-internationalization process: a case study of Marks and Spencer, Palgrave Macmillian, London.

Nowakowski M. K., 1999, Wprowadzenie do zarz̨qdzania miedzynarodowego, Wydawnictwo Difin, Warszawa.

Pietrusiński P., 2005, Mięsynarodowe strategie marketingowe, Polskie Wydawnictwo Ekonomiczne, Warszawa.

Polskie innestycje bespośrednie za granicaw 2012 roku, www.nbp (data wejścia: 04.05.2017). Polskie inwestycje bespośrednie za granica w 2013 roku, www.nbp (data wejścia: 04.05.2017). Polskie inwestycje bespośrednie za granica w 2015 roku, www.nbp (data wejścia: 04.05.2017). Przedsiebiorstwo na rynku miedrynarodonym. Analiza strategiczna, 1994, T. Gołębiowski (red.), Wydawnictwo Naukowe PWN, Warszawa.

Rozkwitalska M., 2007, Zarzadzanie miedzynarodowe, Wydawnictwo Difin, Warszawa. 
Rozwój polskich sieci francsyzouych zagranica 2010, http://franchising.pl/abc-franczyzy (data wejścia: 15.05.2014).

Rudke M., Polskie firmy coraz śmielej poczynaja sobie na śmiatonym rynku, „Rzeczpospolita”, www.rp.pl (data wejścia: 04.05.2017).

Rymarczyk J., 2004, Internacjonalizacja i globalizacja przedsiebiorstwa, Polskie Wydawnictwo Ekonomiczne, Warszawa.

Sznajder A., 1995, Strategie marketingowe na rynku miedrynarodonym, Wydawnictwo Naukowe PWN, Warszawa.

Witek-Hajduk M. K., 2010, Strategie internacjonalizacji polskich przedsiebiorstw w warunkach akcesji do Unii Europejskiej, Oficyna Wydawnicza Szkoły Głównej Handlowej w Warszawie, Warszawa.

World Investment Report 2006, UNCTAD, http://unctad.org/en/pages/PublicationWebflyer.aspx?publicationid (data wejścia: 04.05.2017).

World Investment Report 2009, UNCTAD, http://unctad.org/en/pages/PublicationWebflyer.aspx?publicationid (data wejścia: 04.05.2017).

World Investment Report 2013, UNCTAD, http://unctad.org/en/pages/PublicationWebflyer.aspx?publicationid (data wejścia: 04.05.2017).

World Investment Report 2016, UNCTAD, http://unctad.org/en/pages/Publication Webflyer.aspx?publicationid (data wejścia: 04.05.2017).

Wspótczesne problemy marketingu miedsynarodowego, 1998, J. W. Wiktor (red.), Wydawnictwo Akademii Ekonomicznej w Krakowie, Kraków.

Zorska A., 1998, Ku globalizacji? Przemiany w korporacjach transnarodowych $i$ w gospodarce swratowej, Wydawnictwo Naukowe PWN, Warszawa. 